\title{
FAlSA PÁGina de Don DIEgo
}

David Huerta

La contumacia, la prevaricación y la desmesura no se recatan cuando la infamia las atiza. No lo sabré yo, ¡cuerpo de mí!, que a estas alturas de mi andadura, noramala, tiznado por la desvergüenza, me acojo a los sufragios y benedicciones del sagrado para salvarme, todo o en parte, con lo que me queda de pellejo.

Quisieron hacerme un Cartago y dejarme en piltrafa convertido; pero no se les cumplirá el designio: tengo más vidas que un gato, aunque no soy ladrón cual predican mis maldicientes, y como uno de Algalia más saco el perfume a los azotes y sacudimientos de la ignominia.

Nefandos, malencarados y ellos sí pestíferos a fuer de lodo y de corrupciones, no habrán de verme derrumbado y desvanecido en los berenjenales de la calumnia sino en el altozano de mi nombre y figura puestos en luces y honorabilidad.

¿Que de cuántos delitos me acusan? Escúchese la voz de los callejones y las tabernas donde prosperan los estrafalarios propagadores de mis acusaciones.

Ni una vez sola han de probar su dicho contra mí.

Ha de llegar el minuto en que los redarguya y tache de falsos, en que los reduzca a sus perfiles sucios de mentirosos, en que les cante cuatro verdades y ellos callen hundidos entre zarcillos hirientes y fangales de mendacidad y estupor.

Hágase justicia, digo. Mientras tanto me embozo para ir a maitines junto a mis hermanos protectores. 